\title{
急勾配河川のドライ・ウェットの \\ 境界条件と流量誤差 \\ A DRY-WET BOUNDARY CONDITION AND A DISCHARGE ERROR OF A STEEP GRADIENT RIVER
}

\author{
堀江克也 1 ・森明巨 $2 \cdot$ 西本直史 3 \\ Katsuya HORIE, Akio MORI, and Naoshi NISHIMOTO \\ 1正会員 工修 いであ株式会社 水圈事業部河川部（テ154-8585 東京都世田谷区駒沢3-15-1） \\ 2正会員 工博 いであ株式会社 水圈事業部河川部（†060-0062 北海道札幌市中央区南二条西9-1-2） \\ 3正会員 博（工） いであ株式会社＼cjkstart水圈事業部（テ154-8585 東京都世田谷区駒沢3-15-1）
}

\begin{abstract}
Authors have applied the CRD scheme to the open channel flow, and shown validity as compared with the experiment-with-a-model result or the theoretical value. However, there was a case where a flow error arose at the place where river width changes rapidly. The cause is considered to be dry-wet boundary condition. In the paper, in order to make a discharge error small in a steep gradient river, the dry-wet boundary condition was improved. The improved model was applied to the Toyohira River which is a torrent municipal river. In this calculation, as compared with the past calculation, the discharge error became small.
\end{abstract}

Key Words : numerical computation, contour-integration-based residual distribution, steep gradient river, dry-wet boundary, discharge error

\section{1. はじめに}

著者らは不連続解を持つ流れの多次元解析法として開 発されたCRD法の研究を行っている1), 2),3). CRD法は高 速空気流でその優れた機能が示されており, MacCormack法 ${ }^{4}$ のように陽的に人工粘性を加える必要が なく, Residual Distribution (RD) scheme ${ }^{5), 6), 7)}$ のように複雑 な線形化を必要としない計算法である。 また, 平面二次 元計算では有限要素法のように非構造の三角形格子を用 いるので複雑な地形の扱いが容易である。これまでの研 究では，水理模型実験結果やダム破壊流れなどの理論值 との比較によりCRD法の基本性能を示し ${ }^{1)}$ ，急流都市河 川の豊平川を対象として実河川の大規模洪水時への適合 性を確認した ${ }^{2)}$ 。また，実河川の多様な場（平水位時の 流れや汇濫域など） 一適用するため，CRD法の計算点

（Cell-vertex）に対応したドライ・ウェットの境界条件 について示した ${ }^{3)}$. ドライ・ウェットの境界条件として, 境界付近のウェットの計算点の水理量を補正する方法を 提案し，急縮急拡がある流れの適合性を確認した。しか し，急勾配 (1/100) で厳しい急縮急拡の計算において, 急拡部付近で剥離が生じその下流で流量が増加する場合 があった，その対処法として，計算格子を境界線に合わ せる方法や計算格子を細かくする方法を提案したが，実
河川で容易にCRD法を適用するためには，計算格子への 依存が小さく流量誤差の小さい境界条件を設定する必要 がある。そこで本研究では，急勾配河川にCRD法を適用 する際のドライ・ウェットの境界条件の取り扱いと流量 誤差について論じ，CRD法のモデルの向上を図る.

\section{2. 計算法}

\section{（1） CRD法}

CRD法の計算法は文献1)に示す以下の方法である. 二次元一階双曲型偏微分方程式を式(1)で表す.

$$
\frac{\partial \phi}{\partial t}+\nabla \cdot \mathbf{F}+\Omega=0
$$

ここに， $\phi$ は保存変量， F は流束である. ガウスの発散 定理を使えば，式(1)は式(2-1), 式(2-2)に書き換えられる (簡単のため $\Omega=0$ とする).

$$
\begin{gathered}
\int_{A} \frac{\partial \phi}{\partial t} d A+\Phi^{T}=0 \\
\Phi^{T}=\int_{T} \nabla \cdot \mathbf{F} d A=\oint_{\partial T} \mathbf{F} \cdot d \mathbf{n}
\end{gathered}
$$

ここに， $\Phi^{T}$ はResidualと呼ばれる，A は計算点の支配面 積, $\mathrm{n}$ は計算領域の境界線に外向きの垂直ベクトル, $\mathrm{T}$ は計算要素（ここでは三角形）を表す. $\Phi^{T}$ を式(3)に示 


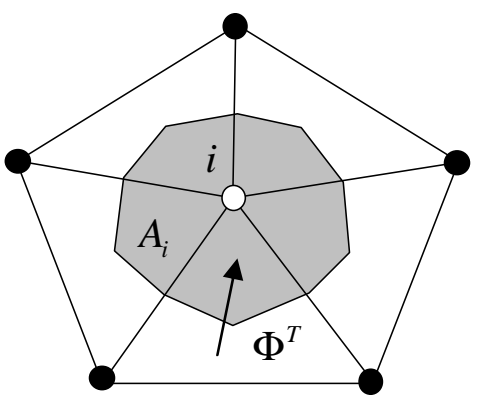

図-1ＣRD法における計算点 (三角形の頂点におく)

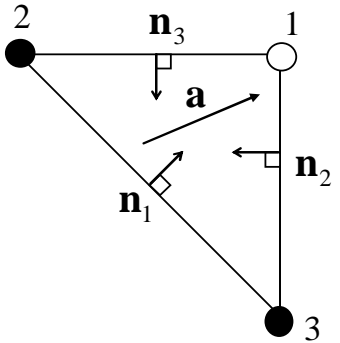

（a）点1に配分する

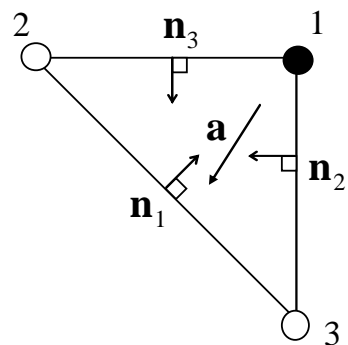

(b) 点2,3に配分する
図-2 Residualの配分法-波動の伝播するa の方向に配分

す係数 $\beta^{T}$ に応じて, 計算点 $i$ 一配分する.

$$
\phi_{i}^{n+1}=\phi_{i}^{n}-\frac{\Delta t}{A_{i}} \beta_{i}^{T} \Phi^{T}
$$

ここに, $n$ は時間ステップ, $\sum_{i} \beta_{i}^{T}=1$ である.

計算には非構造の三角形格子を用いる，計算点は三角 形の頂点（Cell-vertex）にとり（図-1），1つの三角形 格子（計算要素）ごとに独立してResidual $\Phi^{T}$ を計算する。

式(2-1)に左固有べクトル $L$ を作用させて固有べクトル 空間に変換し, $L \Phi^{T}$ をInflow parameter $k_{i}=\mathbf{a} \cdot \mathbf{n}_{i} / 2$ の符 号が正の方向に配分する(風上スキーム).ここに，a 波動の伝播速度, $\mathbf{n}_{i}$ は辺に垂直で計算要素に内向きの ベクトルである．図-2(a)のように $k_{i}>0$ 代1点の場合は 点1に配分寸る. (b) のように2点に向かう場合には多く の方法が提案されているが，本論文では $k_{i}$ の比に応じ て配分する(4)式の方法を用いる. 得られた配分に右固有 ベクトル $R$ を作用させて元の空間に戻し， $\Delta t$ 後の保存 変量 $\phi$ を算定する。

$$
\text { LDA-scheme }^{5)}\left\{\begin{array}{l}
\beta_{2}=k_{2} /\left(k_{2}+k_{3}\right) \\
\beta_{3}=k_{3} /\left(k_{2}+k_{3}\right)
\end{array}\right.
$$

\section{（2）基礎方程式}

平面二次元浅水流方程式は(1)式において,

$$
\phi=\left(\begin{array}{c}
h \\
q_{u} \\
q_{v}
\end{array}\right), \mathbf{F}=\left(\begin{array}{c}
h \mathbf{v} \\
q_{u} \mathbf{v}+g[h] H \mathbf{i} \\
q_{v} \mathbf{v}+g[h] H \mathbf{j}
\end{array}\right), \Omega=\left(\begin{array}{c}
0 \\
f q_{u} \\
f q_{v}
\end{array}\right)
$$

ここに, $h$ は水深, $\mathbf{v}=u \mathbf{i}+v \mathbf{j}, u, v$ は $x, y$ 方向の水 深平均流速, $\mathbf{i}, \mathbf{j}$ は $x, y$ 方向の単位ベクトル, $q_{u}=u h$, $q_{v}=v h, g$ は重力加速度, $H$ は水位, $f=g n^{2} q / h^{7 / 3}$,

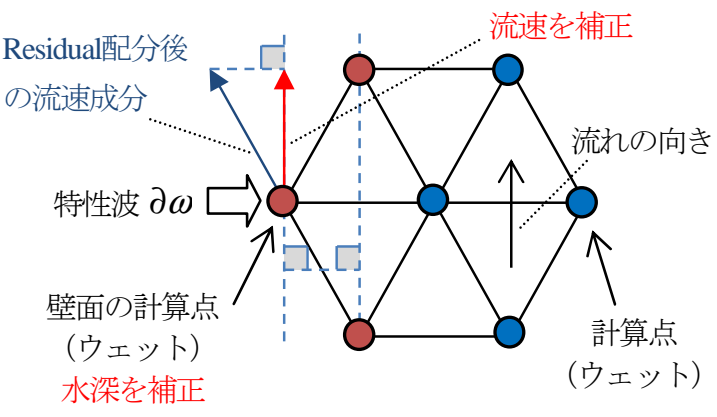

図-3 力学的な壁面条件 (平面図)

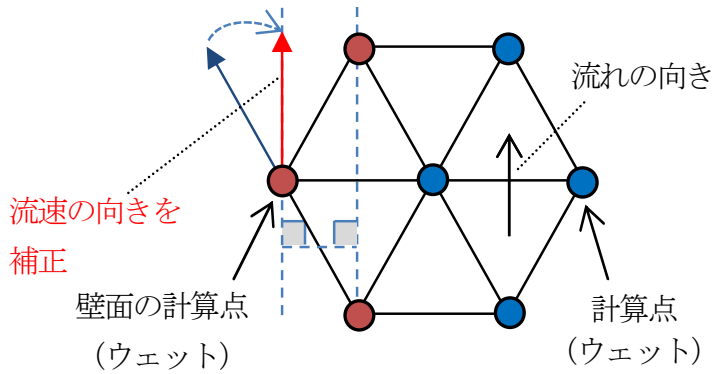

図-4 運動学的な壁面条件（平面図）

$n$ はマニングの粗度係数, $q$ は単位幅流量である. なお, []は計算要素の平均を表し定数として扱う.

\section{（3）抵抗項の取り扱い}

水深がゼロに近く流速が速い場合，式(5)の抵抗項が非 物理的な值となるため, $\Delta t$ 後の保存変量 $\phi^{n+1}$ を算出す る際に式(6)に示すように抵抗項を陰的に取り扱う.

$$
\left(\begin{array}{c}
h \\
(1+f \Delta t) q_{u} \\
(1+f \Delta t) q_{v}
\end{array}\right)^{n+1}=\left(\begin{array}{c}
h \\
q_{u} \\
q_{v}
\end{array}\right)^{n}-\frac{\Delta t}{A_{i}} \beta_{i}^{T} \Phi^{T}
$$

\section{（4）上下流端}

上流端及び下流端においては所定の境界值となるよう に式(7)により計算領域外から特性波 $\partial \omega$ を与える.

$$
\partial \phi=R \partial \omega
$$

\section{3．壁面条件と誤差}

\section{（1）壁面条件}

従来の壁面条件 ${ }^{3}$ は，壁面の計算点において計算領域 外一向から流速成分がゼロとなるように，式(7)により計 算領域外から特性波 $\partial \omega$ を与える方法であり力学的条件 である（図-3）。上下流端の境界条件にも用いている. しかし, 計算領域外に向から流速成分に対応した水深を 補正するため, 計算領域内の水のボリュームが増加する. 流れに対して壁面が並行に近い場合はこの誤差は小さい が，壁面に向かう流れが何度も発生する場合はこの誤差 は無視できない，このため, 図-4に示すように力学的で はないが流速の向きを壁面に沿う向きに補正し, 流速の 大きさと水深は補正せずに運動量を保存させる方法（運 動学的条件）を用いる.この方法により貯水量の誤差が 改善されることを以下に示す. 


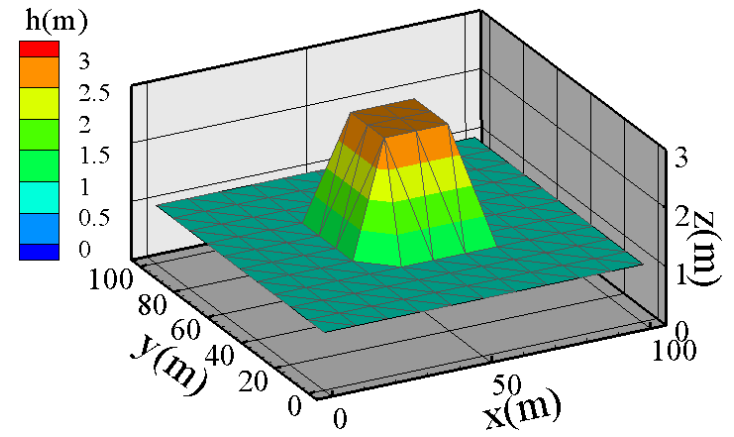

(a) 初期水位

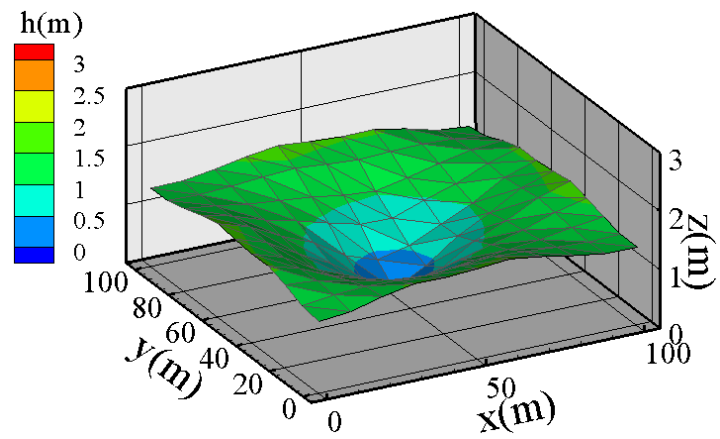

(b) 10 秒後

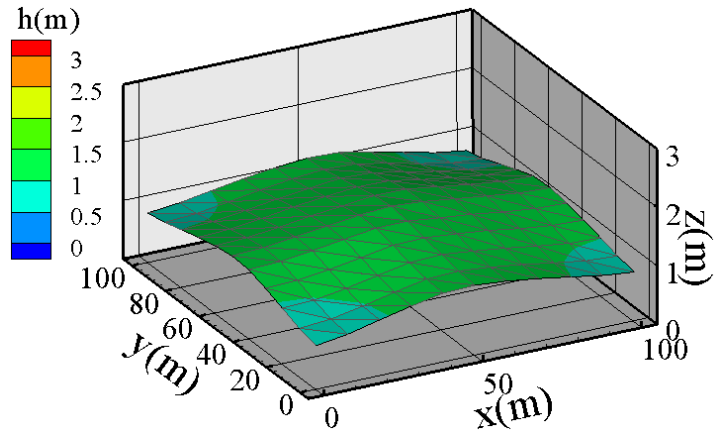

(c) 30 秒後

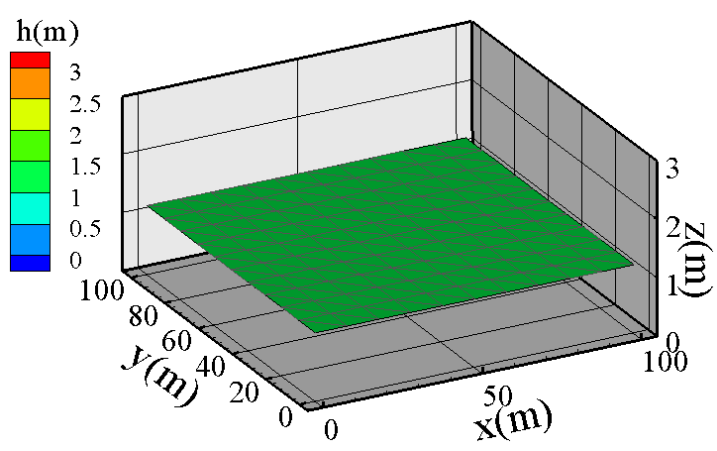

(d) 200 秒後

図-5 水柱崩壊の数値計算結果（運動学的条件）

\section{（2）水柱崩壊の数値計算}

壁面条件の改良の効果を二次元水柱崩壊の数值計算に より確認する. 貯水槽の大きさは縦横 $100.0 \mathrm{~m}$ と, 計算 格子は $\Delta x=\Delta y=10.0 \mathrm{~m}$, 頂角 $90^{\circ}$ の二等辺三角形として いる. 初期水位は貯水位が $1.0 \mathrm{~m}$ ，水柱が中央に $2.0 \mathrm{~m} \times$ $20.0 \mathrm{~m} \times 20.0 \mathrm{~m}$ で存在する．運動学的条件による計算結果 を図-5に示す。水柱の崩壊により水面の波が生じて200 秒程度で水面の波は収束するが，その間に壁面へ向かう 流れが何度か繰り返し起こる。計算初期の貯水量に対す る誤差の時間変化を図-6に示す。力学的条件では貯水量 に約 $8 \%$ の誤差が生じるが運動学的条件では誤差はゼロ である. 力学的条件では壁面に向かう流速を水位に変換 するため，波が収束するまで徐々に貯水量が増加するが， 運動学的条件では流速の向きのみを変更するため貯水量 は保存される.

\section{（3）計算水位の妥当性確認}

運動学的条件による計算水位の妥当性を確認するため, 川幅と河床勾配の変化が著しい山地河川を想定した岡部 $ら^{8)}$ の水路模型実験との比較を行った. 計算格子は $\Delta x$ $=12.5 \mathrm{~cm}$, 粗度係数は 0.02 とし, 下流端水位を $5.8 \mathrm{~cm}$ とし て定常解を求めた。 上流端流量は6.01/sである. 常射流混 在流れであるため，河床変動計算を利用したEntropy Fix ${ }^{3)}$ を使用した。図一7に水路中心線上で計測された実験 水位と運動学的条件による平面二次元計算の断面平均水 位を示す. 力学的条件による計算は文献1）で行われ， 実験水位を良く再現しているが，運動学的条件において も実験水位を良く再現できる，計算領域内の質量誤差 (流入量 - 流出量一貯水量) の時間変化を図-8に示すが, 力学的条件と運動学的条件の質量誤差は共に $1 \%$ 以内で

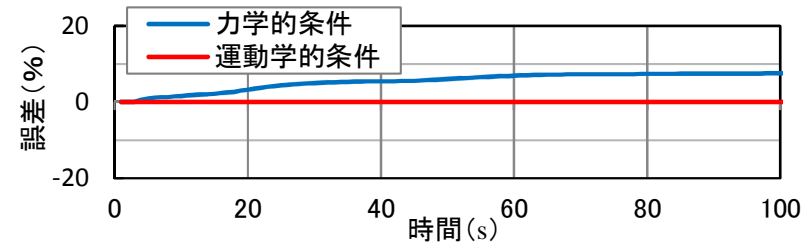

図-6＼cjkstart貯水量の誤差の時間変化
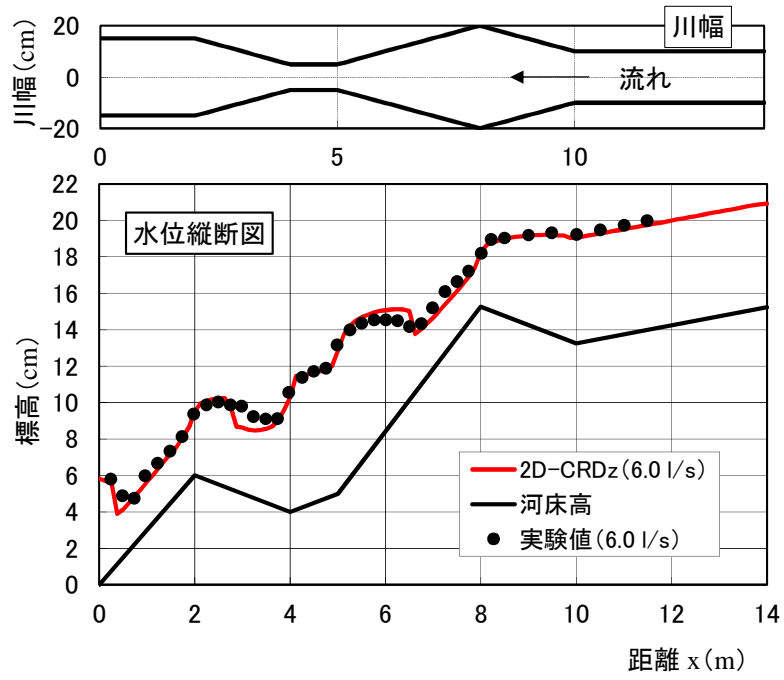

図-7 計算水位（運動学的条件）

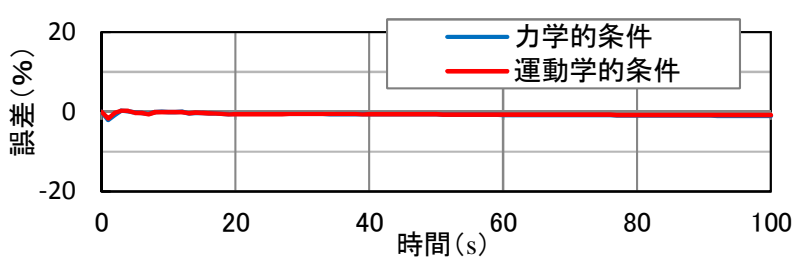

図-8 質量誤差の時間変化（計算領域内） 

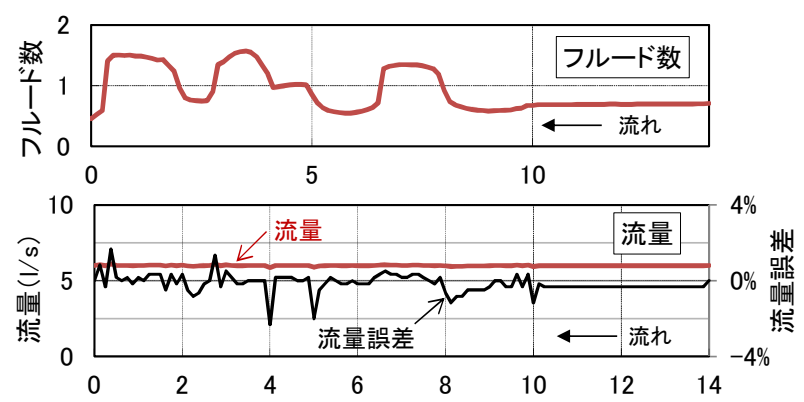

図-9 フルード数と流量誤差（運動学的条件）

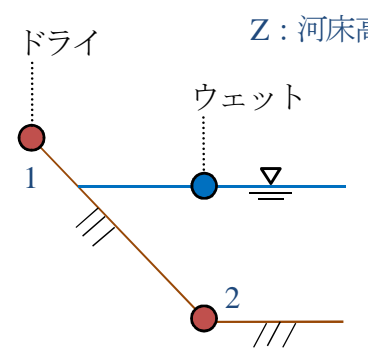

ウェットの計算点 に壁面条件

(a) $\mathrm{Z}_{1}>\mathrm{H}_{2}$

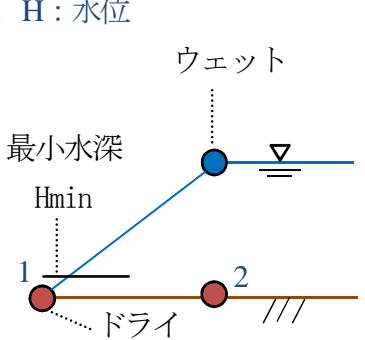

ドライの計算点も含めて Residualを計算

(b) $\mathrm{Z}_{1}+\mathrm{H} \min <\mathrm{H}_{2}$
図-10 ドライとウェットの境界条件（断面図）

あり小さい. 図-9にフルード数と流量縦断図(断面平均 值）を示す，流量は急拡急縮部，河床勾配の変化点など で若干誤差が生じているが，最大で $2.3 \%$ 程度と小さく， その下流では戻っている.

\section{4. ドライとウェットの境界条件と誤差}

\section{（1）ドライの計算点より水位が低い場合}

図-10 (a)のように，ウェットの計算点の水位がドライ の計算点の水位より低い場合，水際のウェットの計算点 に上記3.の壁面条件を適用する. なお，計算時間 $\Delta t$ ごと にドライとウェットの境界線の探索が必要である. 文献 3）では，この方法と同様にウェットの計算点を補正す る方法を提案したが，力学的条件で補正をしており，急 縮急拡が厳しい計算では流量が増加寸る場合があった。 そこで，本研究では文献3）で流量誤差が生じた急縮急 拡が厳しい計算を行い，運動学的条件による改善効果を 確認する. ドライとウェットの境界が計算格子に沿わな いモデル河道である. 河床勾配 $1 / 100$ の直線水路で計算 格子は $\Delta x=10.0 \mathrm{~m}, x=210 \sim 330 \mathrm{~m}$ に水路より $5.0 \mathrm{~m}$ 高い階 段型の高地がある（図-11）。粗度係数は0.030である. 初期水位は急縮部が無い場合の等流水位とし，上流端か ら $50 \mathrm{~m}^{3} / \mathrm{s}$ の一定流量を与えた。 図-12に流速ベクトルーフ ルード数コンター図を示寸。階段型の水際であるが，両 者ともにドライとウェットの境界に沿って流速ベクトル が向いており境界条件の効果が見てとれる. 力学的条件 では急拡部の $(x, y)=(320,50)$ 付近で剥離が生じ Fr $>5$ の 高流速が生じていたが，運動学的条件では見られない． 図-13に計算水位，フルード数と流量誤差，図-14に質量 誤差の時間変化を示寸. 力学的条件では急拡部で流量が

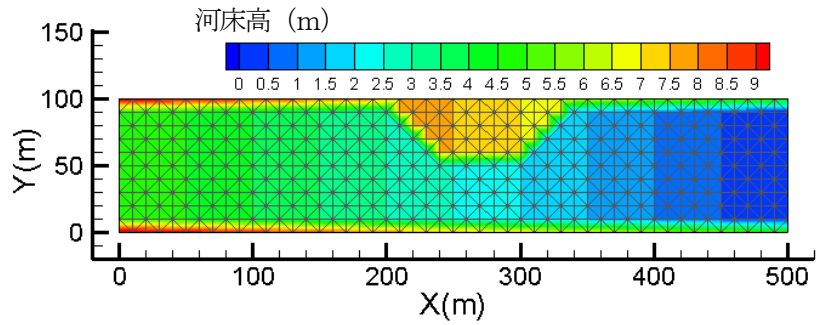

図-11 計算格子と河床高コンター図

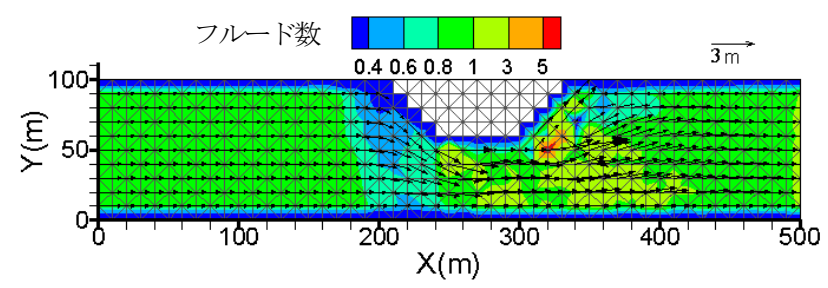

（力学的条件）

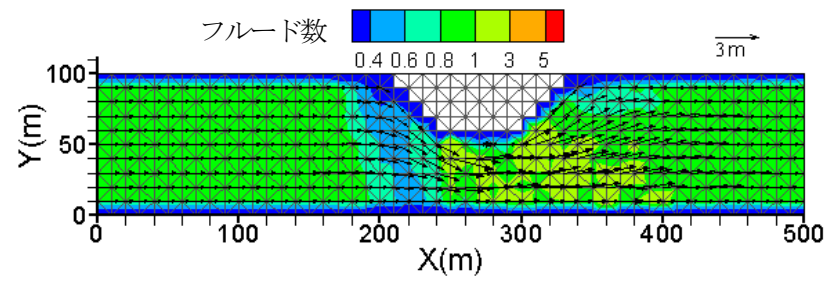

（運動学的条件）

図-12 流速ベクトルーフルード数コンター図
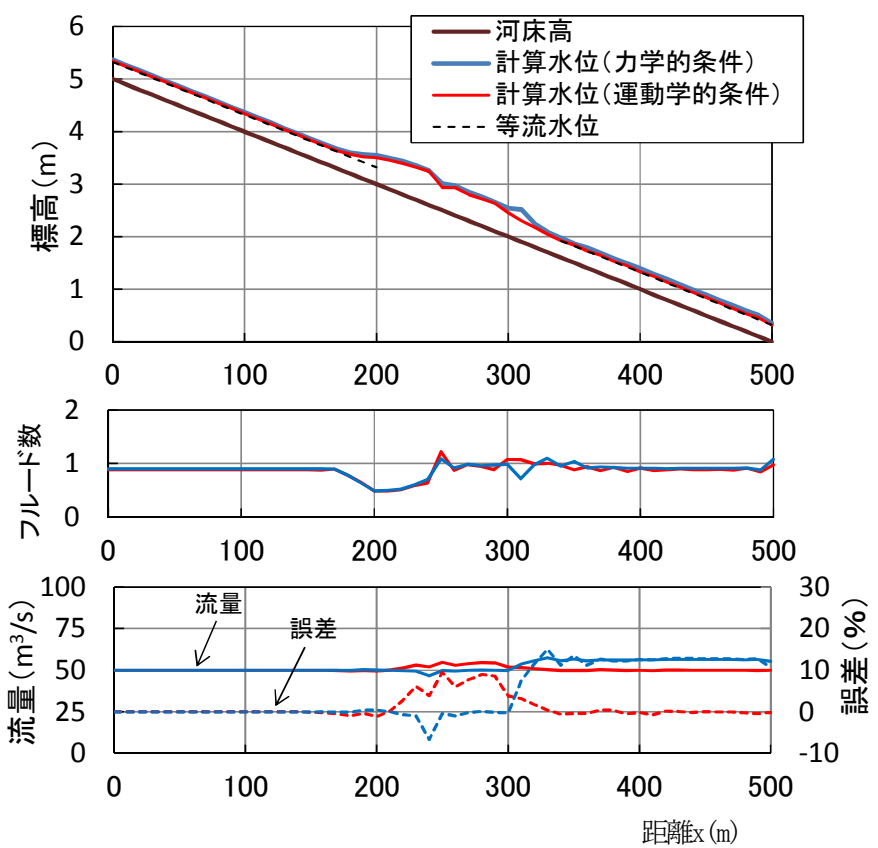

図-13 計算水位, フルード数と流量誤差

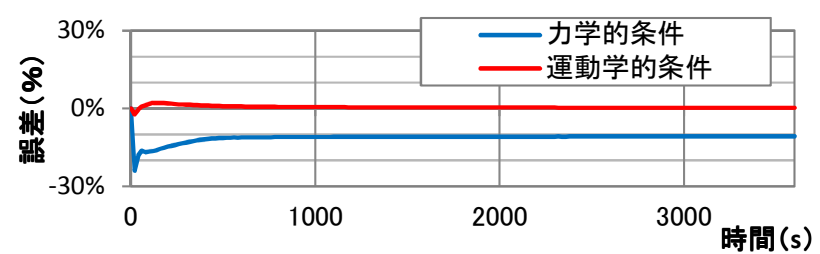

図-14 質量誤差の時間変化（計算領域内）

最大約 $15 \%$ 増加し，水位も等流水位よりやや高くなって いたが，運動学的条件では急拡部下流の流量増加はなく 誤差は $0.2 \%$ 程度である．境界に沿わない計算格子や計 


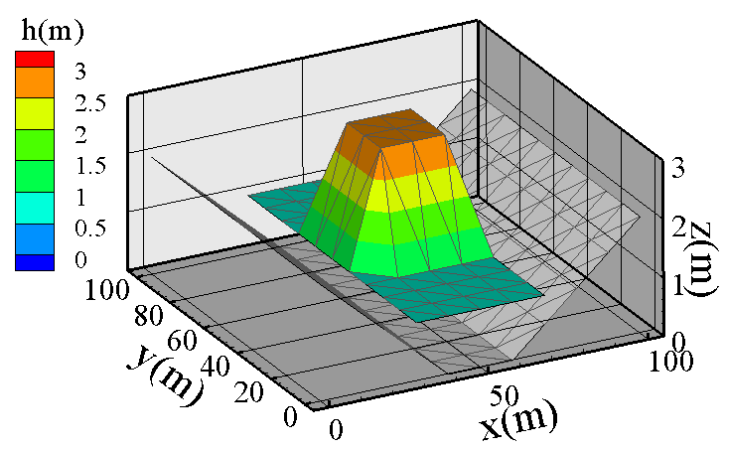

(a) 初期水位

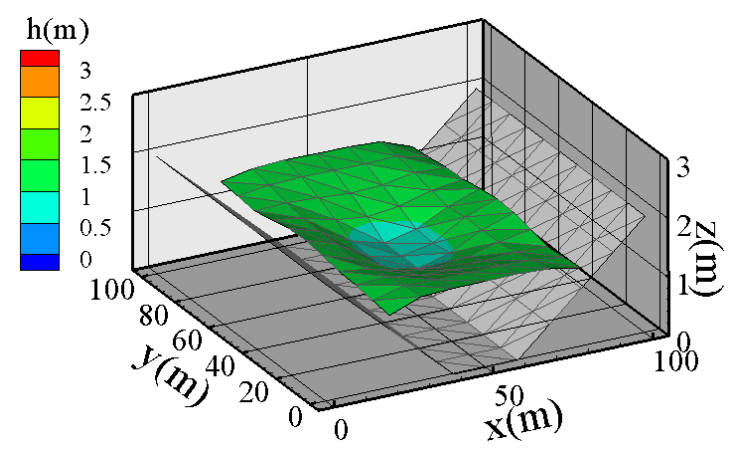

(b) 10秒後

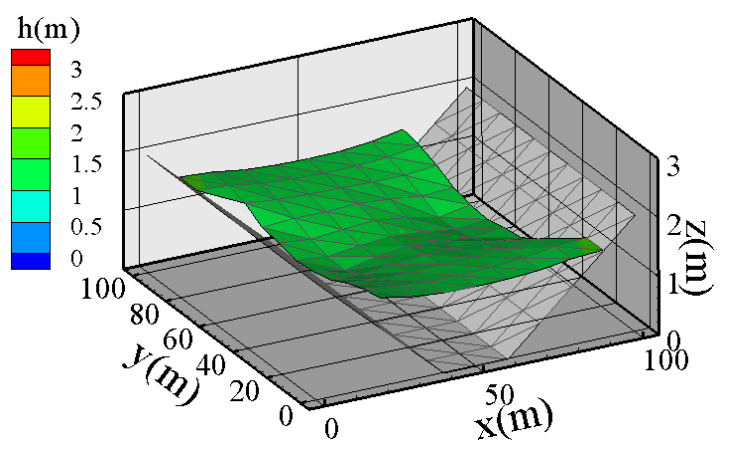

(c) 20秒後

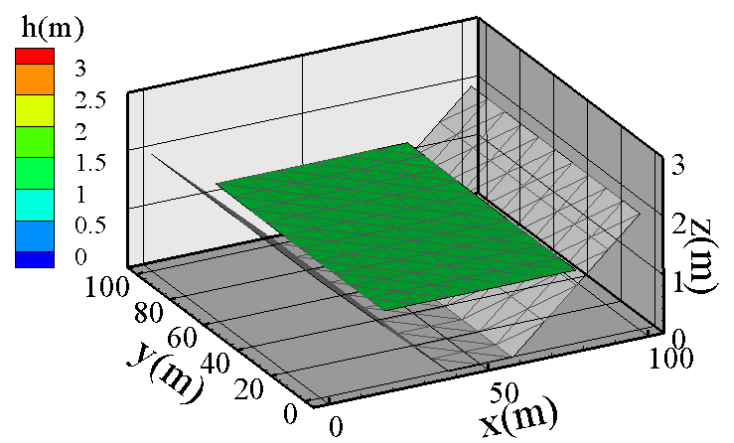

(d) 100 秒後

図-15 水柱崩壊の数值計算結果

算格子を細かくしなくても運動学的条件により流量誤 差・質量誤差が小さくなる。なお，急縮部で最大約 9.5\%の流量誤差が生じているが，この原因は本解析法 が時間1次精度であり急縮部では非定常性が強く精度低 下が生じていると考えられる.

\section{（2）ドライの計算点より水位が高い場合}

図-10 (b)のように，ドライの河床高よりウェットの水 位が高い場合, ドライの計算点も含めてResidualを計算 する.一般にドライベッドの計算点には最小水深を与え て計算を行う9)が，貯水量の誤差を可能な限り少なくす るため, 最小水深は与えずに計算を行う。三角形要素の 1 点がドライで，他の 2 点の水位と比較して図-10 (b) の $\mathrm{Z}_{1}+\mathrm{Hmin}<\mathrm{H}_{2}$ が成立する時にResidualを計算する. Hmin は計算開始の判断水深であり, Residualを配分後にドラ イの水深がHminに到達しない場合でも水深をゼロとし ない.Hminはドライの計算点の地被状況に応じて適切 に与える．なお，水位低下時に水深がHmin以下となる 場合は流速をゼロ，水位が河床高以下となった場合は， 流速，水深ともにゼロとする.

二次元水柱崩壊の数值計算により計算法の確認を行う. 貯水槽の大きさと計算格子は3.(2) と同様とし， $x=40 \mathrm{~m}$, 60mから左右の壁に向かって勾配 $1 / 20$ の河床が存在する. 初期水位は貯水位が $1.0 \mathrm{~m}$ ，水柱が中央に $2.0 \mathrm{~m} \times 20.0 \mathrm{~m} \times$ $20.0 \mathrm{~m}$ で存在し，瞬時に崩壊するものとする．なお， $\mathrm{Hmin}=0.0001 \mathrm{~m}$ とした. 計算結果の水位を図-15に示寸. 水柱崩壊後の 10 秒後, 20 秒後にドライの河床に水面の波 が駆け上がり，100秒程度で収束する。このときの計算 初期の貯水量に対寸る誤差の時間変化は約 $0.08 \%$ である

（図-16）。誤差が大きい時間帯は，計算開始から15秒 から24秒間であり，ウェットからドライに移行する引き

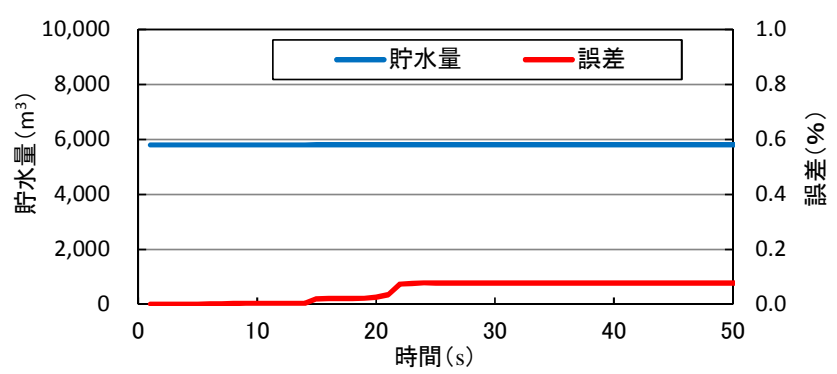

図-16 貯水量の時間変化と誤差

波が発生している（ $y=50 \mathrm{~m}$ 付近）。引き波時に河床か ら水の脇出しが生じ貯水量が増加しているようである. 計算初期から14秒後までは押し波となっているが，最大 の貯水量の誤差は約0.004\%であり微小である.

\section{5. 実河川への適用}

壁面条件とドライ・ウェットの境界条件を改良したモ デルで，急流都市河川である豊平川へ適用した．計算条 件は文献2）と同様とし，昭和56年9月横断測量の地形を 用いて，昭和56年8月洪水ピーク流量 $\left(1,417 \mathrm{~m}^{3} / \mathrm{s}\right)$ を流 下させた。計算結果の水位縦断図（断面平均值），流量 縦断図を図-17に示寸. 1 号床止〜 6,7 号床止下流で支配 断面から跳水が発生しているが，その周辺で流量が変動 している. 力学的条件では5号床止周辺で増加した流量 がその下流まで影響し，下流側の水位が高くなっている が，運動学的条件では床止下流で流量が若干変動するが その下流までは影響せず，流量誤差は最大約 $4 \%$ に収 まっている，模型実験の結果と同様に床止下流の高水敷 でドライベッドが発生しており，運動学的条件を用いる ことで流量誤差が小さくなったと考えられる. 

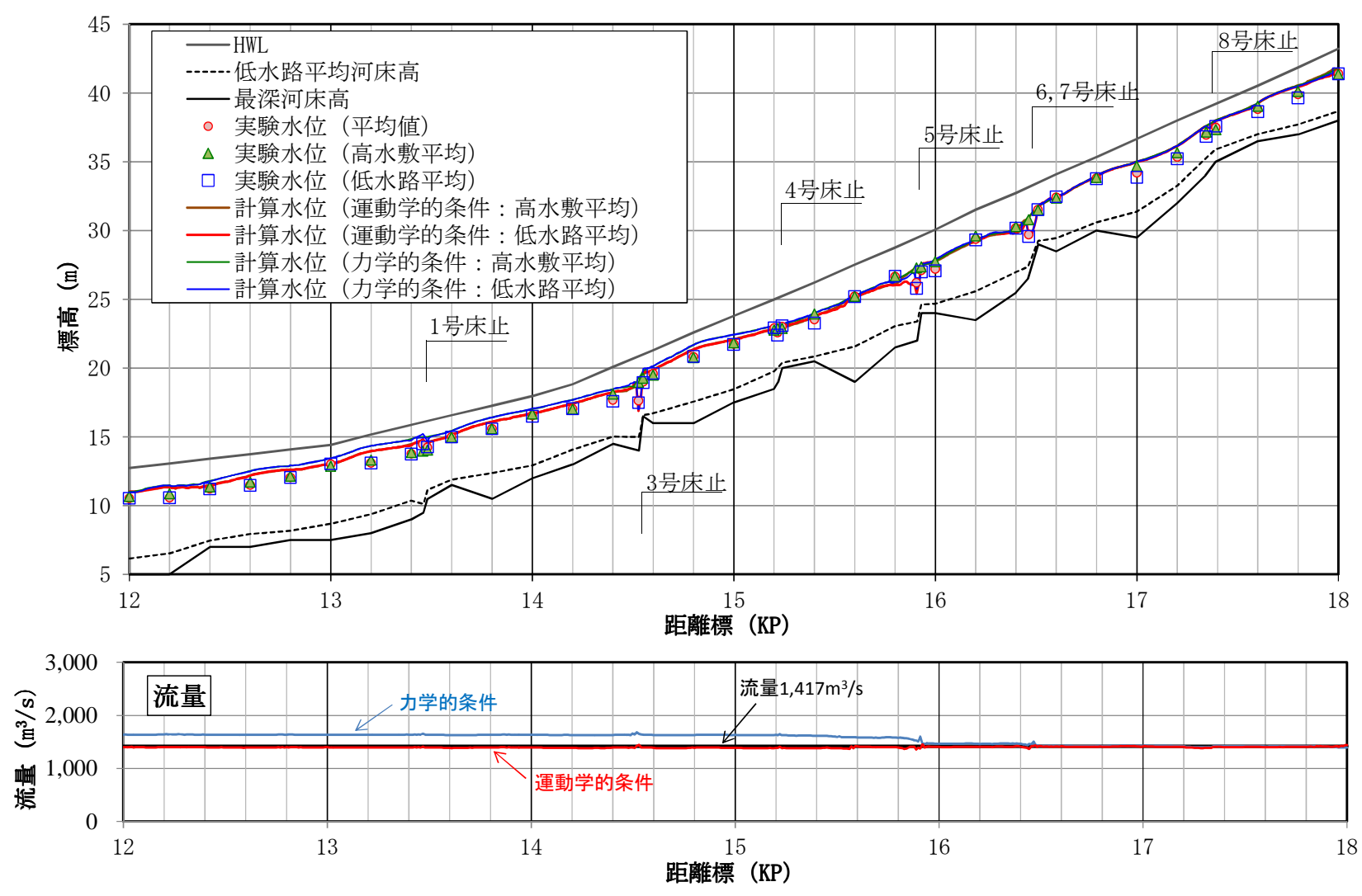

図-17 昭和56年8月洪水ピーク流量を対象とした計算水位と計算流量

\section{6. おわりに}

本論文では，不連続解を持つ流れの多次元解析法とし て開発されたCRD法において，ドライ・ウェットの境界 条件の取り扱いと流量誤差について論じ，急勾配河川で も誤差が小さいモデルへと向上を図った.

第一に壁面条件の見直しを行った．従来の力学的条件 3)では壁面の計算点において流速成分と水深を補正する ため，計算領域外に向から流速成分に対する貯水量が増 加する. この䛊差は平滑域の洪水流の計算においては微 小であるが，急勾配河川で高流速の場合は誤差が大きく なる．このため運動量が釣り合うように流速のみを補正 する方法（運動学的条件）を適用し，水柱崩壊の計算や 既往の実験水位 ${ }^{8)}$ と比較し本解析法が妥当であることを 確認した. 第二にドライとウェットの境界条件について, ドライの河床高がウェットの水位より低ければ計算を行 い，高ければ上記の壁面条件を適用する方法とした。こ れらを修正したモデルを豊平川の昭和56年8月洪水流に 適用し，急勾配で床止が連続する実河川においても流量 誤差が小さい計算が可能となった.

\section{参考文献}

1) 堀江克也, 岡村誠司, 小林雄介, 兵藤誠, 樋田祥久, 西本直史, 森明巨: CRD法を用いた常流・射流混在流れの数值解析, 水 工学論文集, 第55巻, pp.1189-1194, 2011.

2) 堀江克也, 森明巨, 平井康幸, 西本直史: 急勾配河川における CRD法の適用性, 水工学論文集, 第56巻, pp.1231-1236, 2012.
3) 堀江克也, 森明巨, 西本直史: 急勾配河川にCRD法を適用す る場合のドライ・ウェットの境界条件と流量誤差, 水工学論 文集, 第57巻,pp.I_649-I_654, 2013.

4) 例えば崇田徳彦, 清水康行, 渡邊康玄: MacCormack法を用い た常・射流計算, 北海道開発局開発土木研究所月報, No.448, pp.23-32, 1990.

5) H.Paillere, and H.Deconinck.: Compact Cell Vertex Schemes on Unstructured Meshes. In "Euler and Navier-Stokes Solvers Using Multi-Dimensional Upwind Schemes and Multigrid Acceleration" Edited by Herman Deconinck and Barry Koren, Vieweg, 1997

6) 西本直史, 森明巨, 板倉忠興, 金澤克己: FDS法による1次元開 水路流れの数值解析, 土木学会論文集, No.670/II-54, pp.25-36, 2001.

7) 秋山壽一郎, 重枝末玲, 鬼束幸樹, 白川寛樹: 平面 2 次元数值 モデルによる急流都市河川の流況解析, 水工学論文集, 第48 巻, pp.631-636, 2004.

8) 岡部健士, 天羽誠二, 石垣昌邦: 常流・射流の遷移を伴う不 等流の数值計算法について, 水工学論文集, 第36巻, pp.337342, 1992.

9) 例えば秋山壽一郎，重枝未玲,浦勝: 非構造格子を用いた有限 堆積法に基づく1次および2次精度平面2次元洪水流数值モデ ル，土木学会論文集, No.705/II-59, pp.31-43， 2002.

10) 北海道開発局開発土木研究所, 財団法人河川環境管理財団: 平成2年度豊平川大型水理模型実験業務報告書，1990.

(2013. 9. 30受付) 